\title{
Investigating Muslim non-consumers' intention to use Islamic bank: perceived social value (PSV) and awareness
}

\author{
Ery Dwi Pantari, Hendy Mustiko Aji*
}

Faculty of Business and Economics, Universitas Islam Indonesia, Yogyakarta, Indonesia

*Corresponding author: hm.aji@uii.ac.id

\begin{abstract}
As a country with the largest Muslim population in the world, Indonesia has a greater market opportunity for Islamic bank than the conventional. When it compares with other Islamic countries, the market share of Islamic banks is still less appealing. This situation is certainly an interesting problem to be researched. The purpose of this study is to examine the influence of subjective norms, awareness, perceived values, attitudes, and intentions to use Islamic banks based on the Theory of Planned Behavior. This study uses quantitative approach where the data is gathered by distributing the online and offline questionnaires. In total, there are 575 respondents collected. This study finds that Muslim non-customers' intention to use Islamic banks is strongly affected by subjective norms, awareness, and attitudes. It is also found that perceived social value (PSV) does not significantly affect intention to use Islamic banks. This study argues that using Islamic bank is not something 'special' to gain social acceptance or positive image in society. It is also supported by the fact that most Muslims in Indonesia do not use Islamic banks.
\end{abstract}

Keywords: Subjective norms, awareness, perceived values, attitudes, intentions JEL Classification Code: M39 DOI: $10.20885 /$ jsb.vol24.iss2.art8

\section{Introduction}

According to a report issued by the Thomson Reuters Islamic Finance Development Report in 2019, the global Islamic financial assets in 2018 were $\$ 2.5$ trillion and expected to grow by 5.5 percent, reaching \$3.5 trillion by 2024. Meanwhile, Indonesia's Islamic financial industry is in the 5th rank after Malaysia, United Arab Emirates, Bahrain, and Saudi Arabia in the Global Islamic Economic Indicators (GIEI) 2019. The Islamic banking sector is one of the most highlighted in the Islamic financial industry development.

As a country with the largest Muslim population in the world (Pew Research Center, 2009), the Indonesia market for Islamic banks should be better when compared to conventional banks. However, the market shares of Islamic banks in Indonesia until 2017 only reached 5.78\% (Otoritas Jasa Keuangan, 2017). When compared to other Islamic countries, the market share of Islamic banks in Indonesia is still less appealing. Among countries in Asia, Malaysia has the largest Islamic banks market share which is 31.2\%, followed by Bangladesh (19.8\%) (Bank Negara Malaysia, 2018). This situation certainly becomes an interesting problem for further investigation.

In previous studies, awareness has been proven to be the significant factor influencing consumers' intention to use Islamic banks (Muhamad et al, 2013; Abduh and Idrisov, 2014; Albaity and Rahman, 2019; Kaakeh et al, 2019). The results are relatively consistent across countries. In addition to that, the intention to use Islamic banks is also influenced by perceived value (PV). It has been examined by previous studies in various research contexts (Roig et al., 2006; Yee et al., 2011; Khraim et al., 2014; Amjadi et al., 2016), including Islamic banking industry (Abduh and Idrisov, 2014; Fatema et al., 2018). In previous studies, PV has proven to have a significant impact on the intention to use Islamic banks. As in the research of Fatema et al., (2018), they found that PV directly impacts the intention to use Islamic banks in Bangladesh. Even though Abduh and Idrisov (2014) found that PV has no significant effect on intention of using Islamic banks in Dagestan, Rusia. 
Investigating Muslim non-consumers' intention to use Islamic bank:

perceived social value (PSV) and awareness

The results might be different perhaps the dimensions of PV examined are not similar. PV in Abduh and Idrisov's (2014) study was different from Fateema et al., (2018). In the literature, PV is a multi-dimensional construct. As suggested by Sweeney \& Soutar (2001), there are four dimensions of perceived value, namely perceived emotional value (PEV), perceived social value (PSV), perceived price value (PPV), and perceived quality value (PQV). Mostly, studies in the context of Islamic banking associated PV with emotional (PEV) or price value (PPV). Unfortunately, very limited studies raising the issue of social value (PSV) to predict intention to use Islamic banks.

Other prior studies concerning behavioral intention to use Islamic banks have been conducted in various countries (Abduh and Idrisov, 2014; Lajuni, et al, 2017; Obeid and Kaabachi, 2016; Fatema et al, 2018; Alam et al. , 2012). However, the results were inconsistent. In a study conducted by Abduh and Idrisov (2014), Muslim's intention in Dagestan, Rusia to use Islamic banks was significantly influenced by subjective norm and perceived value. Interestingly, they found that public awareness has a significant effect on attitude, but attitude did not influence intention to use Islamic banks. Different results reported by Obeid and Kaabachi (2016) and Alam et al (2012) in Tunisia and Malaysia, in which they found that there is no significant effect of social influence on intention to use Islamic banks and home financing. Attitude which was found insignificantly affect behavioral intention in Abduh and Idrisov's (2014) study, yet was significantly found in the study conducted by Alam et al (2012), Lajuni et.al (2017) and Fatema et.al (2018).

This research contributes to the literature by raising PSV and awareness toward Islamic banks to extend the Theory of Reasoned Action (TRA) model. Therefore, the investigation in this study involves five major variables, such as subjective norms, attitude toward Islamic banks, PSV, awareness, and behavioral intention.

\section{Literature Review and Hypotheses Development}

\section{The Perceived Value of Islamic Bank}

In the literature, perceived value (PV) can be defined as, (1) low price, (2) desire, (3) price for quality, and (4) sacrifice (Zeithaml, 1988). PV is often associated with customer satisfaction and also the service quality. According to Zeithaml (1988), PV and service quality involve evaluative evaluations that are subjective, personal, and context-dependent. Different from satisfaction, PV is felt before using the product, while satisfaction is obtained from experience after using the product (Sweeney and Soutar, 2001). According to Sánchez-Fernández and Iniesta-Bonillo (2007), PV is an implicit criterion used by individuals in making judgments of their preferences. Therefore, it can be unidimensional and multi-dimensional.

In addition to that, Sweeney \& Soutar (2001) suggested four dimensions of PVs, namely perceived emotional value (PEV), perceived social value (PSV), perceived price value (PPV), and perceived quality value (PQV). PEV comes from the feelings or affective states that owned by a product. While PSV comes from the ability of products to improve an individual's social self-concept. The PPV comes from the product in the short term perception and also the long term cost. While PQV is the perception of the expected quality and performance of the product. Previous studies in this topic mainly focused on PPV and PQV, therefore, this study focuses on PSV dimension suggested by Sweeney \& Soutar (2001) as a potential determinant of behavioral intention to use Islamic bank in Indonesia.

\section{Subjective Norm, Attitudes, and Intention to use Islamic Bank}

The theory of reasoned action (TRA), and the theory of planned behavior (TPB) considered subjective norms as social factors or social pressures that a person feels to do or not to do a behavior (Ajzen, 1991). Subjective norm is defined as the degree of social pressure a person feels to do something (Alam et al, 2012). Al-Swidi et al., (2014) defined it as a belief of how a person is going to be viewed in his or her community after conducting particular behavior. It can be divided into societal norm and 
social influence (Pavlou \& Chai, 2002). A person can feel social pressure from anyone around him and then think that he must do a certain behavior (Rahmayah and Aafaqi, 2005). Aji and Dharmmesta (2019) considered subjective norms as external factors that might affect individuals' attitudes. Individual's attitude is easily influenced by subjective norms, such as family members, friends, and colleagues (Amin et al., 2009).

The relationship between subjective norm and attitude has been investigated in the various context of studies, such as unethical behavior (Chang, 1998), organic food (Tarkiainen and Sundqvist, 2005), online shopping (Ramayah and Aafaqi, 2005), Islamic TV advertising (Aji and Dharmmesta, 2019), and technology acceptance (Schepers and Wetzels, 2007). All the studies revealed a significant effect of subjective norm on attitude. As an external factor, perceived social pressure from important people in life who are Muslim majority might influence how a person holds an attitude toward Islamic banks.

The TRA and TPB also showed that subjective norm can predict behavioral intention. It has been widely proven (Taylor \& Todd, 1995; Venkatesh \& Davis, 2000). Prior studies found that subjective norm significantly determined customer's intention to adopt Islamic financing products (Taib et al, 2008; Lajuni et al, 2017). Based on these arguments, the authors therefore propose the following hypotheses:

H1: Subjective norm has a positive and significant effect on attitudes toward Islamic bank. $\mathrm{H} 2$ : Subjective norm has a positive and significant effect on intention to use Islamic bank.

\section{Subjective Norm and Perceived Social Value (PSV)}

Zeithaml (1988) explained that customers' PV toward the use of the product is based on pain and gain. The customers' gain can refer to the benefit perceived when using a product. Meanwhile, the customers' pain refers to things they have been sacrificed for the product, a purchase, for instance (Aulia et al, 2016). According to Fernández dan Bonillo (2007), PV can refer to consumer's social value based on friendship and social image. It means that the social norm and pressure (Pavlou \& Chai, 2002) from important people might affect individual's social image. Even though previous research had not been empirically investigating the effect of subjective norm on PV, yet from the literature review, the relationship can be inferred. Therefore, the following hypothesis is proposed:

H3: Subjective norm has a positive and significant impact on the perceived social value (PSV) of Islamic bank

\section{Awareness and Attitude Toward Islamic Bank}

Brand awareness is the strong attachment of the brand in consumers' memory (Keller, 1993). The awareness toward Islamic banks is defined as consumer's understanding toward the product concept of Islamic banks (Ali et al., 2018; Lujja et al., 2018). People who are more knowledgeable about a particular product or service will eventually become more aware of it (Lujja et al., 2018). In Uganda, Lujja et al., (2018) compared the level of awareness between Muslims and non-Muslims about Islamic banks. They found that $80 \%$ of Muslims were very encouraged to use Islamic banks since they are aware of riba. Some other studies also revealed that awareness can significantly influence attitude towards Islamic banks' products and services (Abduh and Idrisov, 2014; Muhamad et al., 2016; Sabirzyanov, 2016; Albaity and Rahman, 2019; Kaakeh et al., 2019).

Previous research has found that the number of Muslims using Islamic banks is limited due to a lack of awareness about Islamic banks' products itself (Islam and Rahman, 2017). Balushi et al., (2019) found that public awareness becomes one of the factors that make SME owners in Oman intent to use Islamic banks' products and services. It is also found from other studies that awareness toward Islamic banking has a significant effect on intentions to use Islamic banks' services (Kaakeh et al., 2018; Rammal and Zurbrugg, 2007; Obeid and Kaabachi, 2016). Those results can also be extended to current study, in which consumers who are already aware about Islamic banks' products 
characteristics might have positive attitude toward the Islamic banks, and eventually have intention to use Islamic banks. Therefore, this study hypothesizes that,

H4: Awareness has a positive and significant impact on attitudes toward Islamic bank

H5: Awareness has a positive and significant impact on intention to use Islamic bank

\section{Perceived Social Value (PSV) and Attitude Toward Islamic Bank}

Alam et al., (2012) defined attitude as the level of individual interest toward a particular thing, which can be evaluated. PV in general has a significant effect in forming customer attitudes (Molina and Saura, 2008; Kwun, 2011). In a more specific, the perceived hedonic vs utilitarian value is also significantly impact attitudes (Im et al, 2015). In an obvious manner, if the perceived value, especially social value of Islamic bank is good, the customer will put a positive attitude toward the Islamic bank. Besides, PV might also affect purchasing behaviour and customer intentions to use Islamic banks in Bangladesh (Fatema et al., 2018). Similarly in Malaysia, Hashim and Kadir (2010) found that PV has a significant effect on the switching intention Islamic banks. In the context of halal products, 'halal' becomes an important value after the quality and customer satisfaction (Hussain et al., 2016). Therefore, this study hypothesizes that,

H6: Perceived social value (PSV) has a positive and significant effect on attitudes toward Islamic banks

H7: Perceived social value (PSV) has a positive and significant effect on intention to use Islamic banks

\section{Attitude and Intention to use Islamic Bank}

According to Ajzen (1991) the more positive attitude towards a behaviour, the stronger the individual performs the behaviour. The relationship between attitude and intention has been explained by the TRA and TPB. Empirically, it also has been studied in several contexts and locations. In Islamic home financing service in Malaysia, Alam et al., (2012) found that customers' attitude has a direct relationship on behavioral intention to use the Islamic home financing service. Another positive effect of attitude on intention to purchase has also been explained in the context of Islamic banks (Fatema et al., 2018; Lajuni et al., 2017), halal products (Muchtar and Butt, 2012), halal brands (Lada et al., 2009), and halal tourism (Aji et al., 2020). In the context of Islamic banks, previous researchers such as Lada et al., (2009), Amin et al., (2009), and Taib et al., (2008) also has revealed a significant impact between attitudes and intention to use Islamic banks' products. Therefore, this study hypothesizes that,

H8: Attitude has a positive and significant effect on intention to use Islamic bank

\section{Research Methods}

\section{Research Design}

This study uses quantitative approach. The data were obtained after distributing the online and offline type of questionnaires. The online questionnaire was distributed via social media, whereas the offline one was distributed in several places in Yogyakarta, such as universities and several places that can reach many respondents from various regions in Indonesia. Using purposive sampling technique, only Muslims who do not have Islamic bank's account who are eligible to be the respondents.

\section{Items Measurement}

All items examined in this study are adopted from previous literature. Subjective norm is measured by 3-items taken from Alam et al., (2012). Awareness toward Islamic banks is assessed by 6-items modified from Islam and Rahman (2017). Perceived social value (PSV) is measured by 4-items adapted from Abduh and Idrisov (2014). Finally, attitude toward and intention to use Islamic banks are measured by 
items taken from Amin et al (2011). All statements are measured using a Likert scale ranging from $1=$ "strongly disagree" to 5="strongly agree". The research model can be seen in Figure 1.

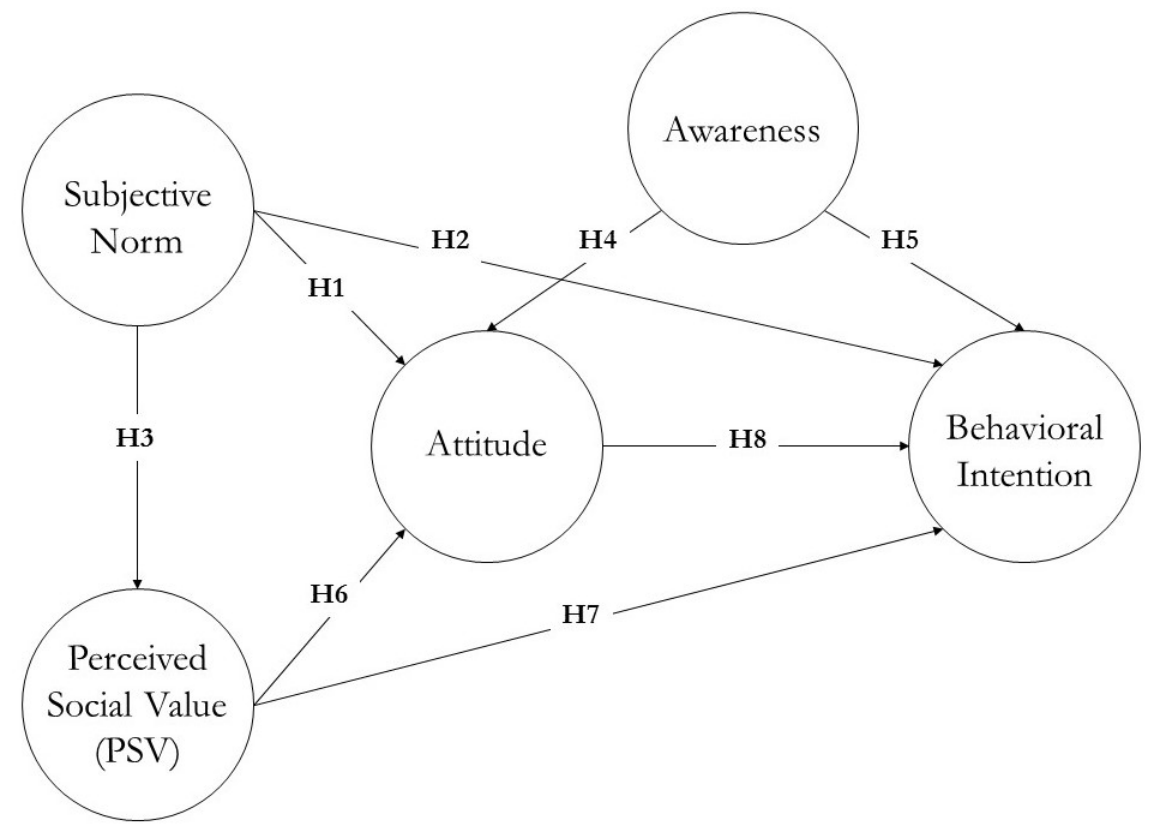

Figure 1. Research model

\section{Results and Discussion}

\section{Respondent Characteristics}

This study successfully collected 575 respondents that are purposively sampled. The data are vary in terms of demographic variables. Male respondents (60\%) are more dominant to female (40\%). Most of the respondents are aged below 30 years old (88.2\%), and there are only $11.8 \%$ who are aged above 30. Even though students are more dominating in this study (72.2\%), however, most of them are married (60\%). Perhaps, most of them are postgraduate students. The respondents are also from several region in Indonesia, eventhough it is lack of proportion. There are 451 (78.4\%) respondents from Java island, which make them the most dominant. It is then followed by respondents from Sulawesi (11.1\%), Kalimantan (5.5\%) and other islands. Complete respondent characteristics can be seen in Table 1.

\section{Measurement Model: Confirmatory Factor Analysis}

In measurement model, the confirmatory factor analysis (CFA) is conducted. In CFA, the model is assessed in terms of items validity and reliability as well as the whole model goodness-of-fit. Convergent validity test is performed using SPSS software. The technique used is the dimensional reduction or factor analysis. Barlett KMO score in this study is 0.94 , which means it's good because it is more than 0.70 (Kaiser, 1974). The items are free from covergent validity issue when the items are converged into factors confirming the theory, and scores $\geq 0.50$ (Hair et al, 2009). The discriminant validity test in this study is measured by the Average Variance Extracted (AVE) score. AVE is said to be valid when the score is greater than 0.50 (Bagozzi and Yi, 1988). Reliability test is assessed by using Composite Reliability (CR) score. The items are reliable if the CR score is $\geq 0.70$ (Hair et al, 2009).

In this study, all factors have weighting score as well as the AVE score greater than 0.50 . Thus, it can be said that the data are valid. Beside, the CR score is also greater than 0.70 , indicating that the data are reliable. The summary of validity and reliability test can be seen in Table 2 . Then 
goodness-of-fit of the model is assessed by using the rule of thumb developed by Hooper et al (2008). Based on the statistical result shown in Table 3, it is found that in general the model is good.

Table 1. Respondent Characteristics

\begin{tabular}{|c|c|c|}
\hline Gender & $\mathrm{N}$ & $\%$ \\
\hline Male & 230 & $60 \%$ \\
\hline Female & 345 & $40 \%$ \\
\hline \multicolumn{3}{|l|}{ Age } \\
\hline$<20$ & 159 & $27.7 \%$ \\
\hline $20-30$ & 348 & $60.5 \%$ \\
\hline $31-40$ & 13 & $2.3 \%$ \\
\hline$>40$ & 55 & $9.6 \%$ \\
\hline \multicolumn{3}{|l|}{ Marriage } \\
\hline Not married & 230 & $40 \%$ \\
\hline Married & 345 & $60 \%$ \\
\hline \multicolumn{3}{|l|}{ Education } \\
\hline Elementary school & 1 & $0.2 \%$ \\
\hline High school & 376 & $65.4 \%$ \\
\hline Diploma 1 & 146 & $25.4 \%$ \\
\hline Diploma 2 & 44 & $7.7 \%$ \\
\hline Diploma 3 & 8 & $1.4 \%$ \\
\hline \multicolumn{3}{|l|}{ Job } \\
\hline Students & 415 & $72.2 \%$ \\
\hline Private employee & 60 & $10.4 \%$ \\
\hline Public employee & 10 & $1.7 \%$ \\
\hline Enterpreneur & 26 & $4.5 \%$ \\
\hline Lecture & 31 & $5.4 \%$ \\
\hline Housewife & 15 & $2.6 \%$ \\
\hline Others & 18 & $3.1 \%$ \\
\hline \multicolumn{3}{|l|}{ Income } \\
\hline$<1$ million & 235 & $40.9 \%$ \\
\hline 1-2,9 million & 211 & $36.7 \%$ \\
\hline 3-4,9 million & 56 & $9.7 \%$ \\
\hline 5-6,9 million & 37 & $6.4 \%$ \\
\hline 7-8,9 million & 15 & $2.6 \%$ \\
\hline 9-10,9 million & 6 & $1.0 \%$ \\
\hline$>11$ million & 15 & $2.6 \%$ \\
\hline \multicolumn{3}{|c|}{ Respondent distribution area } \\
\hline Java & 451 & $78.4 \%$ \\
\hline Kalimantan & 32 & $5.5 \%$ \\
\hline Sumatera & 163 & $11.1 \%$ \\
\hline Sulawesi & 9 & $1.6 \%$ \\
\hline Maluku & 2 & $0.4 \%$ \\
\hline Nusa Tenggara & 9 & $1.6 \%$ \\
\hline Papua & 4 & $0.7 \%$ \\
\hline Others & 4 & $0.7 \%$ \\
\hline
\end{tabular}


Tabel 2. Validity and Reliability Results

\begin{tabular}{|c|c|c|c|}
\hline Statements & Factors weight & AVE & CR \\
\hline Awareness & & 0.568 & 0.936 \\
\hline I am aware that Islamic bank is different from conventional banking & 0.705 & & \\
\hline I am aware that Islamic bank runs on Islamic principles & 0.715 & & \\
\hline $\begin{array}{l}\text { I am aware that Islamic bank is beneficial for all types of religious } \\
\text { customers }\end{array}$ & 0.652 & & \\
\hline $\begin{array}{l}\text { I am aware that my money will not be invested by Islamic bank in } \\
\text { non-Islamic companies, such as alcohol, gambling, etc }\end{array}$ & 0.802 & & \\
\hline I am aware that Islamic bank applies the profit and loss sharing model & 0.762 & & \\
\hline $\begin{array}{l}\text { I am aware that Islamic bank is well managed because the practice is } \\
\text { regulated and supervised by the Otoritas Jasa Keuangan }\end{array}$ & 0.700 & & \\
\hline Intention to use Islamic bank & & 0.786 & 0.788 \\
\hline I am interested in using Islamic bank & 0.767 & & \\
\hline I am interested in using Islamic bank in the future & 0.802 & & \\
\hline I am interested in using Islamic bank one day & 0.803 & & \\
\hline I would recommend Islamic bank to others & 0.657 & & \\
\hline Perceived Social Value (PSV) & & 0.734 & 0.917 \\
\hline Islamic bank helps me feel accepted by others & 0.745 & & \\
\hline Islamic bank makes other people's perceptions of myself positive & 0.846 & & \\
\hline Islamic bank will make other people perceived more positively & 0.788 & & \\
\hline Islamic bank can help their customers to be more accepted by society & 0.794 & & \\
\hline Attitude toward Islamic bank & & 0.688 & 0.898 \\
\hline Using Islamic bank is good & 0.730 & & \\
\hline Using Islamic bank is profitable & 0.824 & & \\
\hline Using Islamic bank is beneficial & 0.784 & & \\
\hline Using Islamic bank is the right choice & 0.672 & & \\
\hline Subjective norm & & 0.555 & 0.887 \\
\hline Most of the people I know are using Islamic bank & 0.835 & & \\
\hline Important people in my life are using Islamic bank & 0.783 & & \\
\hline Most of the people I know think that I use the Islamic bank & 0.588 & & \\
\hline
\end{tabular}

Table 3. Model fit measurement score

\begin{tabular}{ccc}
\hline Criteria & Original score & Category \\
\hline CMIN/DF & 2,8 & Supported \\
GFI & 0,91 & Good \\
AGFI & 0,89 & Good \\
RMSEA & 0,05 & Enough \\
NFI & 0,94 & Good \\
CFI & 0,96 & Very good \\
\hline
\end{tabular}

\section{Structural Model: Hypotheses Testing}

As shown in Table 4, there is one hypothesis which is not supported, but seven others are supported. Subjective norms have a positive and significant impact on attitudes toward Islamic banks. It can be seen from the estimated score of 0.20 with a significance of p-value 0.016 which means $<0,05$. Therefore $\mathrm{H} 1$ is supported. Subjective norms are also proven to have a positive and significant impact on intentions to use Islamic bank since the estimated score is 0.61 (p-value $<0.01$ ) which gives support on H2. Besides, subjective norm is also significantly affect PSV (estimate score is $0.70, \mathrm{p}$ value $<0.01$ ). Thus, $\mathrm{H} 3$ is supported. This study found that awareness has significant effect on both attitude (estimate score $=0.54, \mathrm{p}$-value $<0.01$ ) and intention to use Islamic banks (estimate score $=$ 
0.31, p-value < 0.01). The results support H4 and H5. As hypothesized, PSV is found significantly attitude toward Islamic banks (estimate score $=0.17$, p-value $<0.01$ ), however, it does not significantly affect intention to use Islamic banks. Thus, H6 is supported but H7 is not supported. Lastly, this study found that attitude toward Islamic banks significantly affect intention to use Islamic banks as the estimate score is 0.37 at $\mathrm{p}$-value $<0.01$. This result give support to $\mathrm{H} 8$.

Table 4. Path test result

\begin{tabular}{lccc}
\hline Hypothesis & Estimate & P-value & Result \\
\hline H1 (Subjective norms-attitude) & 0.20 & $* * *$ & H1 is supported \\
H2 (Subjective norms-intention) & 0.61 & $* * *$ & H2 is supported \\
H3 (Subjective norms- perceived social value) & 0.70 & $* * *$ & H3 is supported \\
H4 (Awareness-attitude) & 0.54 & $* * *$ & H4 is supported \\
H5 (Awareness-intention) & 0.31 & $* * *$ & H5 is supported \\
H6 (Perceived social value-attitude) & 0.17 & $* * *$ & H6 is supported \\
H7 (Perceived social value-intention) & -0.10 & 0.134 & H7 is not supported \\
H8 (Attitude-intention) & 0.37 & $* * *$ & H8 is supported \\
\hline
\end{tabular}

\section{Discussion}

The results show that of eight hypotheses tested, there are seven hypotheses which are supported, while one of which is not supported. Subjective norms is proven to have a significant impact on attitude toward Islamic banks. This result supports the findings of Chang (1998), Tarkiainen dan Sundqvist (2005), Ramayah and Aafaqi (2005), Schepers and Wetzels (2007), and Amin et al (2009). Furthermore, $\mathrm{H} 2$ also indicates that subjective norms has a positive and significant effect on intention to use Islamic banks. This indicates that the respondents will tend to have intention to use Islamic banks when their social environment is supportive. This research supports previous research conducted by Taib et al., (2008) and Lajuni et al., (2017). Subjective norms is also found significantly affect PSV. It implies that the higher the social influence received by someone, the person will be more positive in perceiving the social value of Islamic banks.

Besides, this study also reveals that awareness has an influence on attitude toward Islamic banks. These results support Abduh and Idrisov (2014), Muhamad et al, (2016), Albaity and Rahman (2019), Kaakeh et al (2019), and Sabirzyanov's (2016) findings. Awareness also significantly affect intention to use Islamic banks, supporting Balushi et al (2019) who previously investigated the awareness of SME owners in Oman to use Islamic banks instruments. In addition, this result also supports Kaakeh et al (2018), Rammal and Zurbrugg (2007), Obeid and Kaabachi (2016). It can be understood that, without any awareness, an individual cannot give such evaluation about Islamic banks, which eventually do not attract him/her to use Islamic banks. The Islamic banks manager should emphasize more advertising to increase public awareness.

PSV in this study is found to significantly affect attitude toward Islamic banks. This result is in line with the finding from Molina and Saura's (2008), Im et al's (2015), and Kwun's (2011) works in another context. However, interestingly, PSV is found do not significantly affect intention to use Islamic banks. This finding is contradicted with Hashim and Kadir (2010) and Fatema et al (2018) findings, but is supported Abduh and Idrisov (2014). This study argues that using Islamic bank is not something 'special' to gain social acceptance or positive image in society. It is also supported by the fact that most Muslims in Indonesia do not use Islamic banks.

Lastlly, this study revealed a positive and significant effect of attitude impact on the intention to use Islamic banks. In this sense, the more positive the attitude toward Islamic banks, the higher the interest to use Islamic banks. This finding is in fact confirming Theory of Planned Behavior (TPB) and also supporting Alam et al (2012) and Mukhtar dan Butt (2012) in other contexts and Fatema et al (2008), Lajuni et al (2017), Lada et al (2009), Amin et al (2009), and Taib et al (2008) in Islamic banks context. 


\section{Conclusion}

The general objective of this study is to examine some variables that might influence the intention of the Muslim in Indonesia to use Islamic banks. This study concluded that subjective norms, awareness, and attitude have a positive and significant impact on intentions to use Islamic banks. Meanwhile, PSV has no impact on the intention to use Islamic banks.

\section{References}

Abduh, M., \& Idrisov, M. (2014). The Role of Awareness and Perceived Values upon the Acceptance of Islamic Banking and Finance in Dagestan, Journal of Islamic Banking and Finance, Vol. 31, No. 3, pp. 50-60.

Aji, H.M., \& Dharmmesta, B.S. (2019). Subjective norm vs dogmatism: Christian consumer attitude towards Islamic TV advertising. Journal of Islamic Marketing, 10 (3): 961-980. DOI: https://doi.org/10.1108/JIMA-01-2017-0006

Ajzen, I. (1991). The Theory of Planned Behavior, Organizational Behavior and Human Decision Process, Vol. 50, No. 2, pp. 179-211.

Ajzen, I., \& Fishbein, M. (1970). The Prediction of Behavior from Attitudinal and Normative Variables, Journal of Experimental Social Psychology, Vol. 6, No. 4, pp. 466-487.

Alam, S.S., Janor, H., Zanariah, Wel, C.A.C, \& Ahsan, M.N. (2012). Is Religiosity an Important Factor in Influencing the Intention to Undertake Islamic Home Financing in Klang Valley?, World Applied Sciences Journal, Vol. 19, No. 7, pp. 1030-1041.

Albaity, M., \& Rahman, M. (2019.) The intention to use Islamic banking: an exploratory study to measure Islamic financial literacy, International Journal of Emerging Markets, https://doi.org/10.1108/IJOEM-05-2018-0218.

Ali, S.A., Hassan, A., Juhdi, N., \& Razali, S.S. (2018). Employees' attitude towards Islamic banking: measurement development and validation, International Journal of Ethics and Systems, Vol. 34, No. 1, pp. 78-100.

Al-Swidi, A., Huque, S.M.R., Hafeez, M.H., \& Shariff, M.N.M. (2014). The role of subjective norms in theory of planned behavior in the context of organic food consumption, British Food Journal, Vol. 116, No. 10, pp. 1561-1580.

Amin, H., Abdul Rahman, A.R., \& Ramayah, T. (2009). What makes undergraduate students enroll into an elective course? The case of Islamic accounting, International Journal of Islamic and Middle Eastern Finance and Management, Vol. 2, No. 4, pp. 289-304.

Amin, H, Rahman, A.R.A, Jr, SLS, \& Hwa, M.C. (2011). Determinants of Customers' Intention to Use Islamic Personal Financing, Journal of Islamic Accounting and Business Research, Vol. 2, No. 1, pp. 22-42.

Amjadi, F., Yektayar, M., \& Pour, M.K. (2016). Effects of Perceived Value and Its Dimensions on Word of Mouth Advertising Among Customers of Sports Clubs of the City of Sanandaj, Iran, European Journal of Physical Education and Sport Science, Vol. 2, No. 2, pp. 83-89.

Aulia, S.A., Sukati, I., \& Sulaiman, Z. (2016). A Review: Customer Perceived Value and its Dimension, Asian Journal of Social Sciences and Management Studies, Vol. 3, No. 2, pp. 150-162.

Bagozzi, R \& Yi, Y. (1988). On the Evaluation of Structural Equation Models, Journal of the Academy of Marketing Sciences, Vol. 16, pp. 74-94. 
Balushi, Y.A., Locke, S., \& Boulanouar, Z. (2019). Omani SME perceptions towards Islamic financing systems, Qualitative Research in Financial Markets, Vol. 11, No. 4, pp. 369-386.

Chang, M.K. (1998). Predicting Unethical Behavior: A Comparison of the Theory of Reasoned Action and the Theory of Planned Behavior, Journal of Business Ethics, Vol. 17, No. 16, pp. 18251834.

Dodds, W. B., Monroe, K. B., \& Grewal, D. (1991). Effects of price, brand and store information on buyers' product evaluations, Journal of Marketing Research, Vol. 28, No. 3, pp. 307-319.

Fatema, M., Islam, M.A., \& Bakar, R. (2018). Halal Purchase Intention- A Study on Islamic Banks of Bangladesh, The Journal of Social Sciences Research, Vol. 4, No. 12, pp. 402-412.

Fernández, S.R., \& Bonillo, M.A.I. (2007). The concept of perceived value: A systematic review of the research, Marketing Theory, Vol. 7, No. 4, pp. 427-451.

Hair, J., Black, W., Babin, B. (2009). Multivariate Data Analysis. 7th ed. Hoboken: Prentice Hall.

Hooper, D, Coughlan, J, Mullen, MR. (2008). Structural Equation Modelling: Guidelines for Determining Model Fit, Electronic Journal of Business Research Methods, Vol. 6, No. 1, pp. 53-60.

Islam, U.J., \& Rahman, Z. (2017). Awareness and willingness towards Islamic banking among Muslims: An Indian perspective, International Journal of Islamic and Middle Eastern Finance and Management, Vol. 10, No. 1, pp. 92-101.

Kaakeh, A., Hassan, M.K., \& Almazor, S.F.V.H. (2018). Attitude of Muslim minority in Spain towards Islamic finance, International Journal of Islamic and Middle Eastern Finance and Management, Vol. 11, No. 2, pp. 213-230.

Kaakeh, A., Hassan, M.K., \& Almazor, S.F.V.H. (2019). Factors affecting customers' attitude towards Islamic banking in UAE, International Journal of Emerging Markets, Vol. 14, No. 4, pp. 668688.

Kaiser, H.F. (1974). An Index of Factorial Simplicity, Psychometrika,Vol. 39, pp. 31-36.

Keller, K.L. (1993). Conceptualizing, Measuring, and Managing Customer-Based Brand Equity, Journal of Marketing, Vol. 57, No. 1, pp. 1-22.

Khraim, H.S., Al-Jabaly, S.M., \& Aymen S.Khraim, A.S. (2014). The Effect of Perceived Value and Customer Satisfaction on Perceived Price Fairness of Airline Travelers in Jordan, Universal Journal of Management, Vol. 2, No.5, pp. 186-196.

Lajuni, N., Ming, W.W.P., Yacob, Y., Ting, H., \& Jausin, A. (2017). Intention to Use Islamic Banking Products and Its Determinants, International Journal of Economics and Financial Issues, Vol. 7, No. 1, pp. 329-333.

Lapierre, J., Filiatrault, P. \& Chebat, J.C. (1999). Value Strategy Rather Than Quality Strategy: A Case of Business-to-Business Professional Services, Journal of Business Research, Vol. 45, No. 2, pp 235-246.

Lujja, S., Mohammed, M.O., \& Hassan, R. (2018). Islamic banking: an exploratory study of public perception in Uganda, Journal of Islamic Accounting and Business Research, Vol. 9, No. 3, pp. 336-352.

Lyansari, K.N. (2018). Hijrah Celebrity: Creating New Religiosities, Branding Economics of Lifestyle in the Age of Muslim Mass Consumption, Analisis: Jurnal Studi Keislaman, Vol. 18, No. 2, pp. 211-232. 
Malholtra, N.K. (2000). Marketing Research: An Applied Orientation, Upper Saddle River, NJ: Pearson/Prentince Hall.

Muhamad, N.A.N., Hamid, A.A., Bahrom, H., Haniff, M.N., Ab Manan, S.K., \& Aziz, R.A. (2013). Customers' Preference on Islamic Banking Products and Services: the Influence of Knowledge, Awareness and Satisfaction, Malaysian Accounting Review, Vol. 12, No. 1, pp. $1-23$.

Nunnally, J.C. (1978). Psychometric Theory, 2nd ed., McGraw-Hill. New York, p. 245.

Obeid, H., \& Kaabachi, S. (2016). Empirical Investigation Into Customer Adoption Of Islamic Banking Services In Tunisia, The Journal of Applied Business Research, Vol. 32, No. 4, pp 1243-1256.

Otoritas Jasa Keuangan (2017). Snapshot of Indonesia Islamic Banking Development 2017, Direktorat Pengaturan dan Perizinan Perbankan Syariah Otoritas Jasa Keuangan, Jakarta.

Pavlou, P. A., \& Chai, L. (2002). What drives electronic commerce across cultures? A cross-cultural empirical investigation of the theory of planned behavior. Journal of Electronic Commerce Research, 3(4), 240-253.

Pew Research Center (2009). Mapping the Global Muslim Population. Oktober, Pew Forum on Religion \& Public Life, Washington, D.C.

Ramayah, T., \& Aafaqi, B. (2005). Intention to Shop Online Amongst MBA Students: Applicability of the Theory of Reasoned Action (TRA), Proceedings of International Conference on ECommerce 2005.

Rammal, H.G., \& Zurbrugg, R. (2007). Awareness of Islamic Banking products among Muslims: The case of Australia, Journal of Financial Services Marketing, Vol. 12, No. 1, pp. 65-74.

Roig, J.C.F., Garcia, J.S., Tena, M.A.M., \& Monzonis, J.L. (2006). Customer perceived value in banking services, International Journal of Bank Marketing, Vol. 24, No. 5, pp. 266-283.

Sabirzyanov, R. (2016). Produk dan Layanan Keuangan Islam yang Melindungi Perilaku di Tatarstan: Peran Nilai dan Kesadaran yang Dipersepsikan, Jurnal Universitas Raja Abdulaziz, Ekonomi Islam, Vol. 29, No. 1, pp. 111-125.

Sánchez-Fernández, R., \& Iniesta-Bonillo, M.Á. (2007). The concept of perceived value a systematic review of the research, Marketing Theory, Vol. 7, No. 4, pp. 427-451.

Schepers, J., \& Wetzels, M. (2007). A meta-analysis of the technology acceptance model: Investigating subjective norm and moderation effects, Information \& Management, Vol. 44, No. 1, pp. 90-103.

Sweeney, J.C. \& Soutar, G.N. (2001). Consumer Perceived Value: The Development of A Multiple Item Scale, Journal of Retailing, Vol. 77, pp. 203-220.

Taib, F.M., Ramayah, T., \& Razak, D.A. (2008). Factor influencing intention to use diminishing partnership home financing, International Journal of Islamic and Middle Eastern Finance and Management, Vol. 1, No. 3, pp. 235-248.

Tarkiainen, A., \& Sundqvist, S. (2005). Subjective norms, attitudes and intentions of Finish consumers in buying organic food, British Food Journal, Vol. 107, No. 11, pp. 808-822.

Taylor, S., \& Todd, P. (1995). Decomposition and crossover effects in the theory of planned behavior: A study of consumer adoption intentions, International Journal of Research in Marketing, Vol. 12, No. 2, pp. 137-156. 
Thomson Reuters (2018). Islamic Finance Development Report 2018. Desember, Thomson Reuters, Kanada.

Venkatesh, V., \& Davis, F.D. (2000). A Theoretical Extension of the Technology Acceptance Model: Four Longitudinal Field Studies, Management Science, Vol. 45, No. 2, pp. 186-204.

Yee, C.J., San, N.C., \& Khoon, C.H. (2011). Consumers' Perceived Quality, Perceived Value and Perceived Risk Towards Purchase Decision on Automobile, American Journal of Economics and Business Administration, Vol. 3, No. 1, pp. 47-57.

Zeithaml, V.A. (1988). Consumer Perceptions of Price, Quality and Value: A Means-End Model and Synthesis of Evidence, Journal of Marketing, Vol. 52, pp. 2-22. 